\title{
The English Talent Training Mode Based on Theory of Humanism
}

\author{
Zeng-qiang XIA \\ School of Foreign Languages, Henan Institute of Engineering, Zhengzhou, \\ China 451191
}

53996797@qq.com

Keywords: Humanism, Self-directed learning, Relationship between the teachers and students, Self-evaluation.

\begin{abstract}
English teaching can be carried out on the basis of the theory of humanism, whose feasible and effective application in English teaching proves to be true by means of the following three aspects-the students-centered teaching, the equal relationship between the teachers and students, and students' self-evaluation.
\end{abstract}

\section{Introduction}

For a long time, the teachers' presentation is predominant without regarding the students as the principal part of the teaching in traditional English class, which is not good for stimulating the students' interest or cultivating the students' ability in English. Even though some students pass college English Test Band 4 or Band 6, they can't speak English fluently with poor listening. That is so-called silent English. Therefore, the demand of the enterprises for English talent can't be met, which causes the college English teaching to be the focus of the society. According to the requirements of the ministry of education, the present targets of college English teaching includes cultivating the students' comprehensive English ability, especially speaking and listening in order that they can exercise their English skills perfectly in their future job after graduation. So it is absolutely necessary to explore English talent training mode, for which theory of humanism can provide the theoretical basis.

\section{Students-centered Teaching}

After the student become the center of English teaching, the students will take initiatives in English learning, not thinking it as a burden or feeling they are being compelled to learn English. Therefore, the English teacher should study the relationship between teaching and learning so that the students can be given full play to the initiation. Some measures should be taken.

First of all, the designing of the teaching content should be taken into consideration. In terms of the students' interest, habit, capability, such independent and cooperative activities should be designed as oral presentation 5 minutes before class that can be storytelling, songs, poems, imitation of classical English clips. The class activities are centered with students, making them be actively involved in the relative discussions and like that, with the purpose of developing their potential and creativity. The teachers may divide the students into several groups whose activities can be in the form of debating, games, conversations, role plays.

Second, collect and sort out lecture materials. In the students-centered teaching mode, when collecting and sorting out lecture materials, the teachers should think how to give more time and freedom to the students, knowing the students as totally as possible. The majority of students are positive if they are properly guided. The lecture 
materials collected and sorted out before class should be liable to make student take initiatives, be creative, and voluntary.

Third, provide and introduce some sources and materials. The teachers can provide and introduce some sources and materials about English learning to the students, for example, some soft-wares, net platforms (http://www.nhce.edu.cn, http://hee.sflep.co $\mathrm{m})$, the website of BBC,VOA and China Daily where students can practice their listening and reading so that the students may learn English more effectively and autonomically.

Fourth, emotional teaching. During the teaching process, the emotion, attitude between teachers and students may decide the success or failure of teaching. So, by the emotional harmony between teachers and students, English teaching may arouse and cultivate students' interest, help them be confident, improve their ability of learning and thinking, awareness of responsibility, creativity and self-study. As a college English teacher, he or she is supposed to respect and understand students, focus on emotional teaching that plays a significant role in students' astronomical learning.

At last, cultivate significant learning and promote students' all-round development. $\mathrm{C} \cdot \mathrm{R} \cdot$ Rogers divide study into unmeaning learning and significant learning. Sense of learning is the prerequisiteof learning. The teachers should help students know the cognitive meaning and psychological meaning of English learning. If a student simply connect English with such matters as employment ignoring culture inheritance and intercultural communication of English learning. This kind of English learning is meaningless. The effective teaching should escape from the restrict of such exams as college English Test Band 4 or 6. Moreover, the teachers should help students get rid of the thought of chasing fame, be aware of the essence of language and cultural connotation, establish the correct value of learning English, and strengthen the social responsibility and sense of historical mission of learning English. Significant learning is the guarantee of stepping into the smooth way to learning English. Students-centered teaching mode enables the students to become the principle part of the practice of English skills. Only can practice enable students to learn English more effectively. So it is important to guide English teaching with help of significant learning theory.

\section{Establishing Equal Relationship between Teachers and Students}

English teaching process is a communicative process of exchanging and cooperation, involving the all-round emotional communication between teachers and students. Equal, democratic and harmonious relationship between teachers and students can bring about a good and pleasing learning atmosphere, which helps to eliminate students' feelings of oppression, insecurity and alerting. In this way, it is an important psychological environment for students' creativity. Roger's thought of humanism education advocates to establish an equal and harmonious relationship between teachers and students encourages them to take part in the dialogue and communication equally, and gets students to open their minds and give full play to their creativity.

Under the new teacher-student relationship, the teacher is a genuine guider and facilitator, who not only gets along with students equally, but also tries to know, respect and care for them. What's more, the teacher can engage in students' English studying activities on equal terms. It will give the students a feeling of intimacy to watch the teacher taking a role in the role-playing, encourage their interests in learning, improve their English skills, and enliven the class environment. Besides, it is 
necessary to have more conversations with students in the break time. The teacher's caring for students, passion and responsibility for teaching will inspire students' corresponding emotions. Only in this way, can students feel the teacher's sincerity, kindness and caring. It is in such moments that students and teachers will have more smooth and harmonious emotional interactivity. Last but not the least, the teacher's word and deed has a subtle effect. The teacher must know how to use the gentle voice, smiling face and understanding expression, which will endow students a pleasant learning environment. In such environments, students are willing to bring the subjectivity into play and express themselves to the full. Meanwhile, the teacher will experience the joy of it.

Therefore, a good relationship between teachers and students can stimulate students' enthusiasm and maximize their subjective initiative. In the meantime, in order to ensure to carry out the student-centered teaching activities and change the current teaching situation of college English, English teachers should set up a humanistic view of teachers, students and teacher-student relationship, and lay emphasis on both knowledge and emotion.

\section{Advocating Students' Self-evaluation}

Teacher's evaluation to the students has a role of guidance, motivation and promotion, which contributes to a better communication and exchanges between teachers and students. Reasonable and proper evaluation can make students mentally have a correct understanding of themselves, keep students up to the success of psychological suggestion, so that the students in English learning at the same time, to experience the spiritual encouragement and emotional communication. The possibility of the success in learning English will greatly improve, and then implements their own understanding and knowledge of English learning. In addition, in traditional English teaching, the important standard is to evaluate students' performance. But only taking the performance as an evaluation standard of students is too absolute lack of objectivity. Bad grades will have an unfavorable effect on the interest and enthusiasm of English-learning. Therefore, when we emphasize the teachers' evaluation and the students' learning test, the students' independent evaluation should be more advocated. Because under the guidance of humanistic teaching thought, only the active participation of students, self-directed learning, teaching activities can achieve real success. Taking the student as the center means taking students as the main body of teaching. In English teaching, teachers should fully realize the student to be the main part of the English learning, the teacher is a helper, facilitator in teaching activities. This requests us to pay attention to in many ways, in the student-centered English teaching mode, to evaluate students from multiple perspectives, namely teacher evaluation, student test evaluation method and combining the students' evaluation, that is, Students' evaluation is superior to other evaluation methods. Self-evaluation is to let students to use knowledge, summarize, analyze, and judge their English learning and adjust their own study according to the objective reality.

In view of the students' self evaluation, our methods in the teaching activities are as follows: (1) Students are required to submit the learning understanding regularly. Reflect the learning effect in English class, that is, to summarize the harvest, the key points, the questions and the suggestions of learning activities in class. (2) Ask students to make academic record and self evaluation sheet. The group members give each other marks on the sheet for the in-class performance and after-class activities. According to the marks and self-evaluation, students summarize and analyze the 
experience of autonomic learning, and make plans for next English learning.(3) Make good use of disk and net platform of autonomic learning. Students are required to use disk and net platform of autonomic learning and submit the record for the contents and situations of autonomic learning

\section{Conclusion}

Above all, it is significant and meaningful to explore the students-centered English teaching mode, which can generate marvelous effect on cultivating students' comprehensive ability in English learning. It can't be denied that the theory of humanism presents challenge to traditional English teaching. This requires the college English teachers to deal with English teaching with new perspectives. There is no doubt that the theory of humanism has its defects, exaggerating excessively the students' autonomy as well as the inner value of education. So, the reform of English talent training mode must be based on the present actual situation of education, far away from the disadvantages of English teaching, following the scientific road of development in order to adapt to the new demands of economic development of the society.

\section{References}

[1] Liu Runqing. (2000). On College English Teaching. Beijing: Foreign Language Teaching and Research Press.

[2] Tang Dingliang. (2002). Psychology of Higher Education. Nanjing: Hehai University Press.

[3] Xiang Pengyou, Xuling(2002).Teaching and Research of College English. Shanghai: Shanghai Foeign and Education Press.

[4] Yang Xinhui. (2005). A Summary of Western Psychology. Nanchang: Jiangxi Renmin Press. 